\title{
HENRY E. ARMSTRONG*
}

\author{
By Dr. E. F. ArMstrong, F.R.S.
}

$\mathrm{M}^{\mathrm{x}}$ father was essentially artistic in temperament and had a fine sensitivity for many forms of art. Thus he had an ear for and enjoyed music, he derived much enjoyment from his blackand-white pictures, and took an interest in modern pottery. He was unable to take a symphony to pieces, to talk of good and bad construction in composition, or to argue about schools of painting ; but people who do understand these things are often bores and hypocrites of the first order. A good "companion in music" of his writes : "times out of number I have sat with him on the hardest seats imaginable in order that we should go to three concerts in misery rather than to one in comfort. The dear old man was hypnotized by Wagner and Haydn, Beethoven and Mozart, but could not say why-and thank God for it. Your father's appreciation of the arts was, I think, that of the true Artist: underneath the man who possessed a scientific approach to most things lay the makings of a great Artist."

$\mathrm{He}$ had an intense worship for colour either in Nature, on textiles, or elsewhere. Some association of eye effect with the chemical problem of origin gave him a feeling of physical well-being when he viewed a real patch of colour. Some of his happiest days were those spent among the autumn colours, and he wrote with deep feeling about them. His palate was particularly sensitive, especially in later years, to flavour and odour, gifts which led him to find keen enjoyment in fine wines and good food. He never smoked and hated the smell of tobacco except from the best cigars, and in consequence perhaps had a palate of extreme delicacy. In all these matters he was always ready to be educated and acquired much knowledge of the "bitten line" through my collection of etchings, and of wines of virtue through André Simon, greatest and most genial of good companions. It might be said he had a nature abundant in resource which found every moment full of charm. $\mathrm{He}$ never let himself be cabined, cribbed, or confined. This wide range of interests often prevented him from completing a piece of work undertaken with enthusiasm, new problems diverting his attention. He set himself a high standard in his writing and would not allow publication until he was satisfied with the final draft.

$\mathrm{He}$ definitely lacked the engineer's mentality and the appreciation of what the engineer does. Perhaps for this reason he was never in close

- Part of the first Armstrong Memorial Lecture of the Society of Chemical Industry, delivered on February 3. association with his colleague, Unwin, and other leaders of engineering. He tried hard to put the ideal of science and the detective method of scientific inquiry before many generations of engineering students at an age when perhaps they were least receptive of aught else but the practical side of engineering, and perhaps in consequence of failure to interest the many became biased against the engineering mentality.

The students of the Chemical Department at the Central Technical College were few in number, but they made up in quality for any lack of quantity. Practically all of them came to the front in their chosen paths; they were forced to do so by the Professor who admonished them when necessary for their own good. In his day he had a greater personal influence on his men both at College and after leaving than any other professor. He was rewarded when at one period his ex-students or staff held so many of the chairs of chemistry; for example, Wynne, Kipping, Pope, Lapworth, Lowry, Forster, Philip, Crompton, and Percival in Great Britain, and Worley in New Zealand, whilst E. M. Rich became chief education officer to the London County Council.

There exists a list of the careers of his old students showing the many branches of industry into which they have penetrated. Most of them have left their mark on their particular industry either by discovery or by rising to high positions in it, and one is inclined to wonder, after studying it, what would have been the position of chemical industry in Great Britain prior to 1914 if Armstrong had chosen the other path at Finsbury and created there a great school of training for the chemical industries.

It is important to emphasize my father's personal interest in his students, both when at college and throughout their careers. He took the greatest pride in their achievements and worked unceasingly for their promotion. Apart from those he actually taught, there were perhaps quite as many chemists who discussed their researches with him and received much help and guidance, often daily letters, coupled with the frankest criticism. Many others, again, came for advice regarding their careers. His enthusiasm for those who accomplished anything knew no bounds and he threw all his influence behind them. One recalls, for example, a shy schoolmaster, H. B. Baker, working on the reactions of dried gases. His brilliant 
career is well known. My father's correspondence contains a large number of highly appreciative letters from distinguished men, often written on the occasion of their election to the Royal Society.

Armstrong made a point of knowing everybody in chemistry and as many as he could in other sciences; he specially encouraged the younger men and liked them to make the pilgrimage to his house at Lewisham on Sunday. There are many letters testifying to the influence he had on these afternoons. After tea he used to encourage them to talk about their work, and often late in the evening he would write them some suggestions to overcome their difficulties.

Armstrong had a great capacity for making friends and, what is rarer, of continuing to make new friends in advancing years; they had to be men of independent thought. He had the trait of hero worship in his make-up ; all his life he worshipped his teachers Frankland and Kolbe and his friend Dewar, and he had the utmost admiration for many other of his friends; this was particularly brought out in his obituary notices, which were models of graceful feeling. He wrote in reference to Ellwood Hendrick-_.'A friend cannot be defined. He is never made : he comes, when and how who shall say? Only where the wind listeth. He is the greatest and rarest of discoveries : the inestimable loss." Of such quality was the friendship with Dewar, Messel, W. H. Perkin, senr., the Browns, Horace and Adrian.

My father always felt he owed much to the very remarkable scientific quartette at Burton-on-Trent -Peter Griess, Cornelius O'Sullivan and the Browns-all active in the scientific service of brewing. The achievements and influence of these four men on chemical science have been profound. Armstrong has done full justice to it-"They sought neither gain nor applause; love of their art was their guiding light; they were led solely by desire to explore its fields, to grasp its value, to display its beauties."

He frequently went to Burton and corresponded closely with his friends; the introduction to brewing gave him a life interest in this subject, with which he maintained close contact all his life. He pleased to be a good-humoured critic of the quality both of the product and of the science put into it on diverse occasions, and had many friends in the industry. I myself was at one time destined for Burton, but Fate turned my path to biscuits instead of beer.

As a young man my father was extremely earnest and unsociable; my mother had the greatest difficulty in getting him to go anywhere ; he paid only a very few calls on Sunday mornings to old family friends. His whole life was devoted to his work at the College, to teaching and research and to affairs of the Chemical Society. When he came home he wrote letters until late into the night. It was much later in life that he allowed the latent social side to develop, when he had leisure to go about and meet people.

My father shone also as a host; the formal dinner parties at Lewisham were in the true Victorian style, with Clarke, the laboratory attendant, called in as a waiter. The guests were most carefully paired and many interesting people came to the house. One such party included Sir George Robertson, the hero of Chitral, and Prince Kropotkin, then a prominent Russian revolutionary, though to-day his politics would be considered the palest of pink. We had no cellar book like Saintsbury, but a visitors' book was maintained from 1894 and in time it became an honour to be included in it. It is truly international; every American or German chemist who came to London made the journey to Granville Park, generally on a Sunday, and the names of few of the British chemists of the day are missing. A frequent entry is that of Joji Sakurai. His is the last name in the book; he called on May 21, 1937, when my father was confined to his room. My sister tells me that at 3 o'clock in the afternoon a half bottle of champagne was sent for so that the two old gentlemen might drink to one another. Sakurai passed away on January 28, 1939.

In his later years Armstrong became the guest par excellence. Adorned with his coloured waistcoats, his one personal vanity, though he claimed them as an advertisement for the achievements of the dye industry, he became a much-sought table companion at the dinners of the Omar Khayyam Club, the Saintsbury Club, the Wine and Food Society and many similar occasions; he enjoyed also the banquets of the London Livery Companies. His knowledge was so wide, his range of subjects so varied, his views so original and outspoken that they aroused the interest of his table companions. Very often correspondence and friendships followed these chance meetings.

One dining club merits special mention, namely, the original Chemical Club, which was an exclusive body, limited to forty chemists elected by ballot; it met monthly on the same days as the Chemical Society. Formed in November, 1872, the first secretary was Pedler, but Armstrong took on the task in the following February and continued to perform it for many years until the constitution changed and the dining club became associated with the Council of the Society. The history of most dining clubs is much the same. They either become too formal and dull and so lapse, or they depend on the enthusiasm of one man and a set 
of regular participants. The old Chemical Club took the latter path ; it became entirely informal, minutes, rules and subscriptions were in abeyance and it relied on Armstrong, or rather Mrs. Armstrong, to send out the monthly cards and order the dinners. Here the older men were met on level terms by the younger, and many enduring friendships were formed. Here also it was possible to entertain appropriately distinguished foreign visitors to our shores.

My father took delight also, when the Chemical Dining Club was no more, in arranging dinners at the Athenæum and elsewhere to distinguished visitors to London, when representative Londoners widely chosen were gathersd to meet them.

The successor to the Chemical Club has been the Catalysts, now also a mature body. Armstrong was seldom absent from these dinners and did much to make them enjoyable. He was a regular chairman also at the monthly lunch meetings of the Old Centralians, a gathering which gave him lively satisfaction.

"He that enlarges his curiosity after the works of nature demonstrably multiplies the inlets to happiness."-Johnson, Rambler No. 5.

Academic life gave my father full opportunity for holidays, and he enjoyed the absence from London. He enjoyed walking and continued it into the 'eighties and would have no other sport. I remember Lockyer trying to get him to take up golf on Blackheath. A regular Sunday morning walk across Blackheath to the Observatory in Greenwich Park will always be associated by me with his memory.

In his early youth he walked a good deal in Scotland; later he went abroad to Switzerland and Norway, then just opening up for tourists, often in company with Tilden or Clowes.

For the family holidays which played so large a part in his life, Margate was at first the chosen place. Here he had Lauder-Brunton and Hardy, the eye specialist, among others, to see ; Lockyer was at Westgate. In later years the geological general practitioner Dr. Arthur Rowe was his great friend there. We were taught at an early age to waik; to study the changes in the soft chalk, in that district very rapid; to look for fossils ; to visit churches and to learn the history of the Roman occupation and of the Cinque Ports.

Beginning about 1886, Lyme Regis was chosen for Easter. The Tildens came too, also Wynne; Lord Lister lived at the top of the hill. By that time we youngsters could walk farther, but even so the ascent of Golden Cap was a feat, and more than one visitor found the two miles or more of shingle along the face of the intervening hill enough for that holiday.
A visit of the Geologists' Association took us to Swanage one Easter (1895) and there and then the cottage on the pier was secured for the summer and for many future holidays. Here the family was trained in nature study - to collect, to observe, to record as part of a normal enjoyable holiday. One of his children should have become a biologist, nurtured under such environment, but heredity or some other factor proved too much for us and we have remained normal people taking perhaps a special interest in our holidays and collecting as a hobby. The Isle of Purbeck is still a unique centre for study with three geological ages in juxtaposition, involving three different flora and fauna. My father gave much time to his coastal photography here ; it involved carrying around a heavy camera, tripod and glass plates, and sundry adventures by way of trespass or in boats to secure pictures of selected sections.

We had the ambition to walk round the English coast on the coastguards' path and in course of time accomplished all the worth-while sections, writing up the experiences in the form of illustrated and annotated log books. We were induced in this way to look up the history or other information relating to places and objects, and so learnt at an early age how to consult books of reference and make a précis of information. This training was of the utmost value ; it helped to teach us to learn easily anything which appeared of interest, though we were as stubborn as other children in refusing to learn the dull stuff taught at school. None of us was high in class except in our pet subjects which we mastered with ease.

The transference of affection to the Lake District came later, the introduction being effected on a Geologists' Association trip led by Marr. Here Armstrong had his happiest days and he returned to Manesty Farm near Grange, with its unique views into the jaws of Borrowdale in the one direction and across Derwentwater to Skiddaw and Saddleback in the other, as often as possible each year for many years. Long walks were carefully chosen to give variety and interest, and formed a programme of increasing severity to suit all weather conditions. Some of the most arduous gave him greatest joy; the long grind round to the top of Grasmoor, the attack on Gable from Green Gable via the side of the slate quarry on Honister, the walk up Ennerdale and the climb out at the head of the valley, the ascent from Seathwaite to below Great End and the climb up Cust Gulley were some of his favourites. Another was the ridge walk to Causey Pike followed by an abrupt descent that often caused havoc to his companions, in which he took secret delight. The use of a car to lessen road distances and make new walks possible in later years added greatly to his enjoyment. 
He loved having visitors at Manesty, and very many came there; he would talk freely on the hills and in the sitting room on slack or wet days and gave mental stimulus, as only he knew how, to not a few. He made friends with the parson, Canon Rawnsley, at Keswick, and took an active part in all the fights to preserve the Lake District against vandalism. The greatest joys of all to him were the days when the snow came and gave yet one more touch to the kaleidoscope of colour on rock and hillside. Those who knew him in the hills perhaps saw him at his best and most versatile -2 philosopher, wise in very varied knowledge, more full of zeal than tolerance, perhaps, putting the cause above worldly ambition.

Armstrong was strongly individualistic and gloried in being so ; in his later years he enjoyed being provocative and exaggerated his attacksin his own words-" "there is more fun in laying about you." As a freelance without occupation he had not often the opportunity to be constructive. In a wiser age perhaps his abilities would have been more utilized.

It must be remembered that he was the product of an age when transport was slow and communication limited-the horse and buggy days of our American cousins. Whereas there were then many small local worlds, to-day there is only one large world in which the radio brings an event to the notice of everyone within a few seconds of its happening. Science and philosophy to-day more than ever seek to submerge the particular in the universal; there is little room for the unique individual, who is looked on as irrational. The desire of the human mind is for unification; all that is, was, or ever shall be, originates from one source. Most students to-day accept this view as a doctrine of scientific faith and regard one who combats it as outside reason. Hence perhaps the failure of the youngest generation to appreciate Armstrong's greatness. Had he lived fifty years earlier he would have been venerated for the very reason that he had been criticized. Hence the fact that his outpourings in scientific journals were most appreciated by older men and in the United States, which is still largely individualistic.

As an adventurer Armstrong could not understand the satisfaction to be gained from committees and conferences. Immediate action appealed to him; the need of the cause was too urgent to allow time in which to placate the opposition. It has been said that disapproval occupies the greater part of our conversation; it is tempting to say how a job ought to be done when one is denied the opportunity to do it.

Progress, educational or otherwise, means hard fighting not for one lifetime only but for genera- tions. Those whom Priestley termed "the men who will never learn" are strong. Meredith's simile of the hair, in that remarkable work the "The Shaving of Shagpat", as illustrative of the errors, iniustices or illusions which an enormous effort is required to destroy, appealed very much to my father. His ideals were those for which we are fighting to-day. To him they were clear and patent. In an address in 1935 to the Frankland Lancastrian Society he wrote, "as human beings most of us are only interested in ourselves. We have to learn without delay how much more we might, could, and should do for ourselves." $\mathrm{He}$ outlined some of the immediate needs of the nation and emphasized how the inquiry will demand an extraordinary use of intelligence which in large measure will have to be developed for the purpose. We are trying to do these very things in 1940-41, under difficulties of which "the hair" is the greatest.

My father was a great reader. Probably no one knew the chemical literature up to a certain period better than he did and he possessed a most retentive memory. In later years with more leisure he read very widely. He appreciated that "the worth of reading is in its after effects; it forces big thoughts and compels the recognition of new aspects of common things." His writings are full of quotations, Lewis Carroll being one of his favourite authors for this purpose.

$\mathrm{He}$ mentions the influence of Trench's book "The Study of Words" on his youthful impressions and his then habit of omnivorous reading. $\mathrm{He}$ gladly returned to this when he gave up his professorship. The influence of good companions is to be found in his later writings,. which were often brilliant apart from their pungency.

Some words of Lafcadio Hearn are, I think, appropriate to him, namely, that if a man has a very powerful imagination as well as a very large sympathy the study of science alone will give him everything he needs. "He can get the water of emotion out of any desert of dry facts." Hearn says that such men are very rare, and students of science, who normally tend to be hard, are counselled to read emotional literature. I think it will be agreed that his addresses of later years are full of feeling; he took enormous pains with them.

My father had a wonderful old age; he found something to do every day, kind friends to encourage him and though his hearing began to fail, his vitality and mental energy were unabated. Only on the death of his wife in the last days of 1935 did ill-health overtake him. He bore a long period in his room with great patience and preserved his mental faculties to within a week of his passing on. 
He accepted the creed of Ben Ezra, who so boldly declares that old age is better than youth simply because of its being the time of knowledge and understanding.

He has marked Browning's verse :

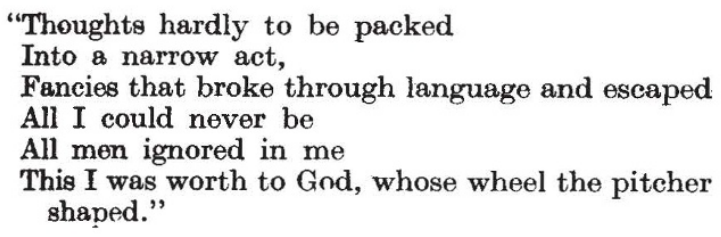

He hoped much from heredity and believed the best qualities of a man may appear in his grandchildren or great grandchildren; they furnish the proof of the worth of the ancestor, using the words of Lafcadio Hearn. The tragic death of his grand- son, Kenneth Frankland Armstrong, in whose career H. E. A. took so much pride, was perhaps the greatest blow of his life.

I have sought to trace the life-history of a versatile, individualistic man ; one who kept himself fit in body and also in mind; one who gave unstintingly of his best to many causes without thought of fame or honour for himself; it was indeed his nature to decline all such. If the task has been achieved we have seen what is so well expressed in the words of Walt Whitman :

"Journeyers gaily with their own youth,

Journeyers with their bearded and well-grained manhood,

Journeyers with their own sublime old age :

Old age, calm expanded, broad with the haughty breadth of the universe."

\title{
'WORKING-CLASS' EARNINGS AND EXPENDITURE
}

\author{
By D. Caradog Jones, \\ School of Social Sciences and Administration, University of Liverpool
}

\section{Definition of 'Cost of Living'}

$\mathrm{T}$ HE nominal wages of a working man are in the main governed by the demand for and the supply of such skill as he possesses. His real wages-what he can buy with his money-depend upon the movement of prices. During a war, the mounting cost of living invariably directs public attention to the need for regulating wages so that real and nominal shall keep step. The 'Cost of Living' Index was designed for this purpose in 1914 and has been widely used ever since.

'Living' clearly has a very different meaning in different social circles, so that changes in the cost of living of different classes cannot be accurately measured with the same instrument. Agreement must accordingly be reached upon a standard, a definition of living, if we are to measure its changing cost. The purpose of the Ministry of Labour Index is to measure the average increase in the cost of maintaining unchanged a standard of living of the working-classes as defined in 1914. Strictly, therefore, this index is a measure of price changes-the mean change in price of an aggregate of certain specified commodities the enjoyment of which constitutes 'living'. The choice of these commodities was based on an analysis of 1944 urban working-class family budgets collected by the Board of Trade in 1904, but between 1904 and
1914 the Sumner Cost of Living Committee (1918) reported that "no considerable changes took place in the mode or standard of living". These budgets indicated that, in spite of a wide divergence in expenditure between families, certain needs are common to them all. These basic needs alone, things which from time to time practically every family buys, are used to define living. The number included in the 1914 calculations was severely limited ; the list of foods, for example, contained only fourteen commodities: no fruit and no vegetables, except potatoes, were included. In such respects the standard of living of the workingclasses has risen considerably since the War of 1914-18; to this improvement the cultivation of allotments, advance in the science of preserving and storing food, quicker transport from abroad have all contributed. Consequently, an analysis of household budgets to-day reveals a marked extension of the field of basic expenditure.

\section{New Collection of Household Budgets}

The first results of the recent and most elaborate budget inquiry ever undertaken in Great Britain by a Government department were published in the Ministry of Labour Gazette, December 1940. The households invited to keep budgets-and encouraged to do so by a small payment for each 